\title{
MODELLING OF THERMODYNAMICAL AND DYNAMICAL PROPERTIES OF MAGNETIC STRIPES ON 2D HEXAGONAL LATTICE *
}

\author{
A. Joknys and E.E. Tornau \\ Semiconductor Physics Institute, A. Goštauto 11, LT-01108 Vilnius, Lithuania \\ E-mail: et@et.pfi.lt
}

Received 12 June 2007

\begin{abstract}
The model with competing exchange $J$ and dipole-dipole $D$ interactions on 2D hexagonal lattice is studied using Monte Carlo method. We calculate the energy, specific heat, order parameter, and susceptibility of the system close to the phase transition point $T_{\mathrm{c}}$ from stripe phase to isotropic stripe phase. This allows us to determine phase transition points for different values of exchange and dipole-dipole interaction ratio $\eta=J / D$ and calculate the phase diagram for transitions to stripe phases AF $h$ of different stripe width $h$. By using histogram method we determine the order of the transition at $T_{\mathrm{c}}$. The first order phase transition was found to AF1 and AF2 phases and the second order one to AF3 and AF4 phases, with tricritical point being close to the AF2 and AF3 phase boundary in the phase diagram. We also calculate the structure factor above and below $T_{\mathrm{C}} \mathrm{s}$ to AF1, AF2, AF3, and AF4 phases. Studying the dynamical properties of the model we have found that in AF1 phase and in a part of AF2 phase the spin relaxation corresponds to the Ising model dynamics. In phases AF3 and AF4 the dynamics slows down, and stripe domain growth with time is proportional to $\log t$. With further increase of parameter $\eta$ and approaching the ferromagnetic phase the dynamics satisfies the Ising model dynamics again.
\end{abstract}

Keywords: phase transitions, stripes, ferromagnetic and dipole interactions, Monte Carlo method

PACS: $61.46 . \mathrm{Bc}, 68.35 . \mathrm{Rh}, 68.18 . \mathrm{Jk}$

\section{Introduction}

Self-organized domain structures in form of droplets, bubbles, or stripes are often found in two-dimensional systems with long-range electrostatic, magnetic, or elastic interactions. For example, electrostatic dipole interactions induce stripe-like phases in Langmuir multilayers in water-air interface [1]. Three types of competing $\mathrm{O}-\mathrm{Cu}$ interactions, with repulsive long range forces caused by substrate mediated elasticity, are responsible for $\mathrm{Cu}-\mathrm{O}$ stripes in partly $\mathrm{O}$-covered $\mathrm{Fe}(110)$ [2]. Strain and domain wall effects cause the formation of periodic domain structures in the oldest of known ferroelectrics, Rochelle salt [3].

In certain magnetic thin films and nanostructures long-range dipole-dipole interactions between magnetic spins are as important as short-range exchange interactions. If these two forces are competing (e.g. exchange interactions are ferromagnetic (FM) and dipole-dipole interactions are antiferromagnetic (AF)),

\footnotetext{
* The report presented at the 37th Lithuanian National Physics Conference, 11-13 June 2007, Vilnius, Lithuania.
}

the periodic magnetic domain structure, consisting of stripes with one magnetization direction alternating with stripes of opposite direction, might occur in the system. The width of stripes $h$ in units of lattice spacing $a$ depends on a ratio of these interactions. If dipole interactions are dominating the stripes are narrow, if short range interactions are prevailing the stripes are broad or FM phase occurs. The best known experimental realization of a magnetic striped system is ultrathin films of $\mathrm{Fe} / \mathrm{Cu}(001)$. In these films magnetization switching from perpendicular to in-plane direction is found with increase of film thickness [4]. At very small film thickness, when magnetization is perpendicular to film plane, different topological stripe defects as well as direct transition between isotropic and straight stripe phases [5] and even inverse transition effects [6] are found.

Surface (perpendicular) anisotropy of very thin films (in a range 2.3-5.3 monolayers of $\mathrm{Fe}$ in $\mathrm{Fe} / \mathrm{Cu}(001)$ [4]) prevails over in-plane anisotropy of thicker films, caused by dipole-dipole interaction, thus making the magnetic moments in an ultrathin film analogous to 
Ising spins. This fact allows for a simple theoretical description of magnetic properties of these films in terms of a FM Ising model plus only one additional dipolar term decaying with distance as $r^{-3}$. The first Monte Carlo calculation using this model on a square lattice, in which stripe phases of different widths were found at low temperature, was performed by McIsaak et al [7]. Very soon the same group [8] found that stripe phase melting with increase of temperature happens via the intermediate isotropic phase with short range order and perpendicular corners between stripe domains. The finding of this intermediate phase confirmed earlier prediction of Abanov et al [9] (obtained using the continuous approximation) that the transition stripeparamagnetic phase has to be mediated by the phase called "tetragonal liquid".

Classifying the phases and using liquid crystals terminology (in terms of topological defects), the following situation might be expected in a system with competing exchange and long-range interactions [10]: at low temperature the smectic (stripe) phase possesing both long-range orientational and spatial order is observed. At finite temperature it may contain bound pairs of dislocations in a form of stripe termination and therefore slight distortion of nearby stripes. Spatial order in this phase decays algebraically with distance. At higher temperature the phase transition from smectic to nematic phase might occur. In nematic phase orientational order is maintained, spatial order depends on distance exponentially and unbinding of dislocations into pairs of disinclinations is observed. A disinclination is the point at which two domains, in which the stripes are oriented in different directions, meet and terminate. At still higher temperature the transition to tetragonal phase on a square lattice or transition to hexatic phase on hexagonal (triangular) lattice is expected. In these phases orientational order is lost and magnetic moments have the symmetry of the underlying lattice. The transition to the tetragonal or hexatic phase is characterized by the unbinding of disinclinations.

Thus in agreement with predictions of Abanov [9], stripe-tetragonal phase transition was found in calculations for a square lattice [8], but in contrast to these predictions the phase transition sequence stripes-nematictetragonal was not found.

In recent years different aspects of the Ising model with competing exchange and dipolar interactions were studied on a square lattice. Gleiser et al found the metastable phase in between AF1 $(h=1)$ and AF2 $(h=2)$ phases of the phase diagram [11] and calculated the dynamics of domain growth in this region [12]. In
Ref. [13] two different types of magnetization relaxation were found. Calculations of thermodynamic properties and structure factor on very large lattices were performed in Ref. [14]. The type of transition into the stripe phase was analysed in Refs. $[15,16]$.

Stoycheva and Singer $[17,18]$ performed the only study we know of this model on a hexagonal lattice. Visual evidence suggests that the type of the stripe melting transition they obtain is Kosterlitz-Thouless type unbinding of dislocations of the stripe phase into disinclinations of the isotropic (hexatic) phase. They showed, by using both Monte Carlo calculations and analytical theory, that decreasing repulsion (dipole-dipole) strength leads to crossover from defectmediated stripe melting to usual spin-disordering. They were trying to demonstrate Kosterlitz-Thouless mechanism of transition at stripe melting point: by increasing the size of the lattice up to $7^{6}$, they showed that the peak of heat capacity at the transition point decreases with system size.

The Ising model with competing short-range and long-range interactions and the planar ( $X Y$, KosterlitzThouless) model with $p$-fold symmetry breaking orientational field $[19,20]$ are rather similar. For the planar model very different predictions for the cases $p=$ 4 (square lattice) and $p=6$ (hexagonal lattice) are drawn. In the latter case the phase transition sequence disordered $\rightarrow$ isotropic quasiliquid $\rightarrow$ ordered phase is anticipated with decrease of temperature $[19,20]$. In the case of a square lattice the intermediate phase is expected to have a vanishingly small stability region. Therefore it is not obvious at all that the study of a stripe melting transition on a square lattice would give similar results as that on a hexagonal lattice.

In this paper we study Ising model with competing exchange and dipolar interactions on a hexagonal lattice. The Hamiltonian of the model has the form

$$
\mathcal{H}=-J \sum_{\langle i \neq j\rangle} s_{i} s_{j}+D \sum_{\langle i \neq j\rangle} \frac{s_{i} s_{j}}{r_{i j}^{3}},
$$

where $J$ is a FM interaction constant and the first sum is restricted to pairs of the nearest neighbour spins. In the second sum $D$ is dipolar interaction constant and site indices $i$ and $j$ run over all $N$ sites of a hexagonal lattice. In Hamiltonian (1) we consider the sum over every pair of spins in dipolar term just once. The spin variables $s_{i}= \pm 1$, and the spins are supposed to be aligned out of plane. By using Monte Carlo method, in Section 2 we calculate the thermodynamic parameters of the model, determine the phase transition point $T_{\mathrm{c}}$ to the stripe phase for different values of interaction 
parameter $\eta=J / D$, and present the phase diagram. Further everywhere the temperature $T=k_{\mathrm{B}} T(\mathrm{~K}) / D$ and the interaction parameter $\eta$ are in dimensionless units. By applying the histogram method we calculate the order of the phase transition into phases of different stripe widths in Section 3. We present the structure factor of our system (below, at, and above $T_{\mathrm{c}}$ ) in Section 4 . The dynamic properties of the model are studied in Section 4.

\section{Phase transition thermodynamics and phase diagram}

To obtain the phase transition point $T_{\mathrm{c}}$ into the stripe phase we calculate the temperature dependence of the energy per spin $E=\mathcal{H} / N$, the specific heat $C_{V}=$ $\left(1 / T^{2}\right)\left(\left\langle E^{2}\right\rangle-\langle E\rangle^{2}\right)$, the order parameter, and the susceptibility of the model (1) for four main phases AF1, $\mathrm{AF} 2, \mathrm{AF} 3$, and AF4. We perform the calculations by Monte Carlo method using Metropolis algorithm on a hexagonal lattice of $N=48 \times 48$ spins, including the long-range dipolar interactions up to the distance of 24a. The size of the lattice and the cut-off we found
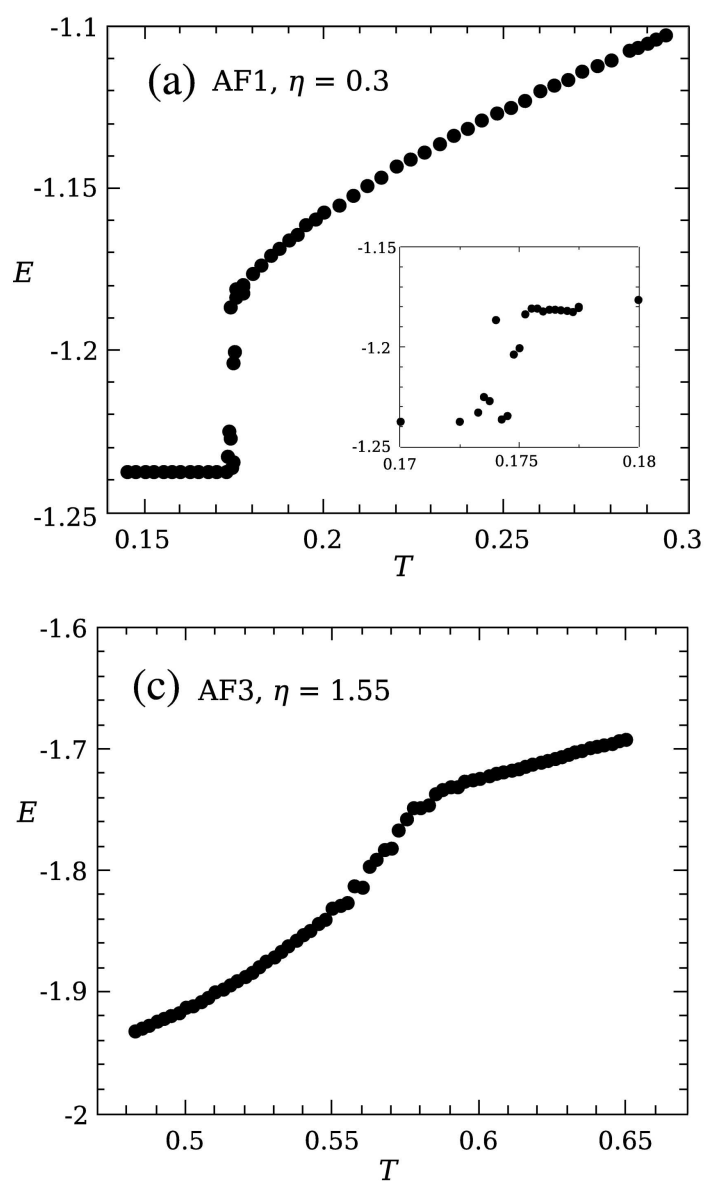

optimal for calculations of the phase transition thermodynamics and dynamics, since further increase of lattice does not add to accuracy of $T_{\mathrm{c}}$ determination.

The order parameter is constructed to find the orientational alignment in stripe interfaces. For the square lattice the order parameter defining the phase transition from stripe phase to isotropic melted stripe phase has the form $\left|\left(n_{\mathrm{h}}-n_{\mathrm{v}}\right) /\left(n_{\mathrm{h}}+n_{\mathrm{v}}\right)\right|$, where $n_{\mathrm{h}}\left(n_{\mathrm{v}}\right)$ is the number of horizontal (vertical) bonds between antiparalel neighbouring spins [8]. For hexagonal lattice it is convenient to use its analogue in a form proposed in Ref. [17]

$$
g_{2}=\left\langle\left|\frac{1}{N} \sum_{i, j} \delta_{s_{i},-s_{j}} \mathrm{e}^{2 \mathrm{i} \theta_{i, j}}\right|\right\rangle
$$

where delta function $\delta_{s_{i},-s_{j}}$ retains only nearest-neighbour spin pairs of opposite (interface) spins. The vector joining such a pair makes the angle $\theta_{i, j}$ with a reference direction, and $\mathrm{i}$ is imaginary unit. The parameter $g_{2}=$ 0.5 in a stripe phase and zero in isotropic or disordered phase. Thus the susceptibility is obtained from the formula $\chi=(1 / T)\left(\left\langle g_{2}^{2}\right\rangle-\left\langle g_{2}\right\rangle^{2}\right)$.
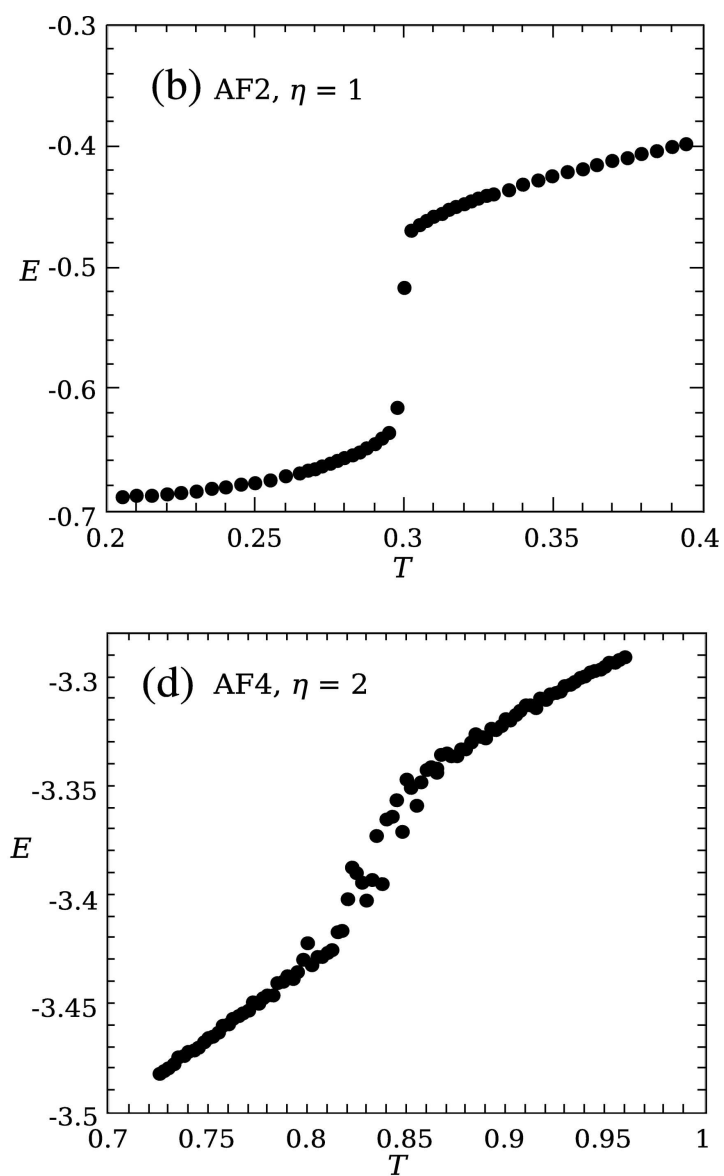

Fig. 1. Temperature dependences of mean energy close to the $T_{\mathrm{c}}$ point for (a) AF1, (b) AF2, (c) AF3, and (d) AF4 phases. 
The stripe melting transition point $T_{\mathrm{c}}$ is found from temperature dependences of specific heat and susceptibility. The $E(T)$ dependences in thin stripe phases $\mathrm{AF} 1$ and $\mathrm{AF} 2$ are also good indications of the $T_{\mathrm{c}}$ point. In Fig. 1 we present $E(T)$ dependences in all four AF phases. It is seen that the energy in the phase transition region of phases AF1 and AF2 changes abruptly, in contrast to the $E(T)$ dependence for phases with broader stripes which is inclined and much stronger influenced by the fluctuations. The same tendency might be seen in temperature dependences of order parameter (Fig. 2). Correspondingly the peaks at $T_{\mathrm{c}}$ of $C_{V}(T)$ and $\chi(T)$ are sharp and narrow at the transitions to AF1 and AF2 phases and more flat at those to AF3 and AF4 (see Figs. 3 and 4) and even broader stripe phases.

Using thus obtained $T_{\mathrm{c}}$ data at different $\eta$ values we present in Fig. 5 the phase diagram of the model (1) for hexagonal lattice. Determination of the stripe phases with $h>4$ for hexagonal lattice is rather difficult, because thicker stripes do not anymore maintain the stripe configuration with fixed thickness. Due tue stronger fluctuations and defects the thickness of the stripe is spacially alternating in low temperature stripe phase as well as in isotropic melted stripe phase. Compar-
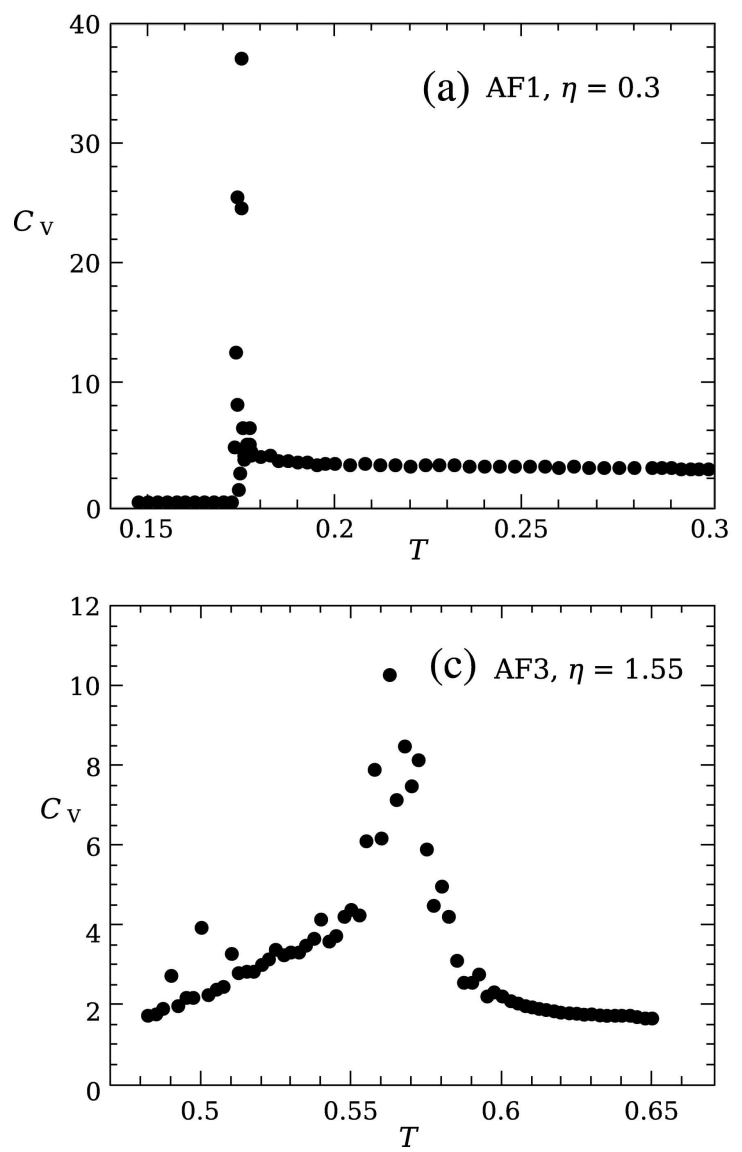

ing our phase diagram with the similar diagrams obtained for the square lattice $[7,11,14]$, we can notice that the phase boundaries AF2-AF3, AF3-AF4, and $\mathrm{AF} 4-\mathrm{AF}$ (with $h>4$ ) roughly correspond to those obtained for the square lattice multiplied by $3 / 2$, the ratio of number of nearest neighbours in hexagonal and square lattices [21]. We did not find such a correspondence for the AF1-AF2 boundary.

\section{Transition order}

Analysis of temperature dependences of main transition parameters in four $\mathrm{AF}$ stripe phases indicates that in the $\mathrm{AF} 1$ and $\mathrm{AF} 2$ phases the stripe melting transition is, most likely, of the first, while in the $h>2$ phases it is of the second order. The study of the transition order for the square lattice using fourth order cumulant and histogram methods $[16,15]$ determined the weak first order transition for the AF2 phase and second order transition for the AF3 phase. The transition order in the AF1 phase was not unambigously defined, since the twin-peaked structure was not found in energy distribution $P(E)$ at the transition point. In our calculation of
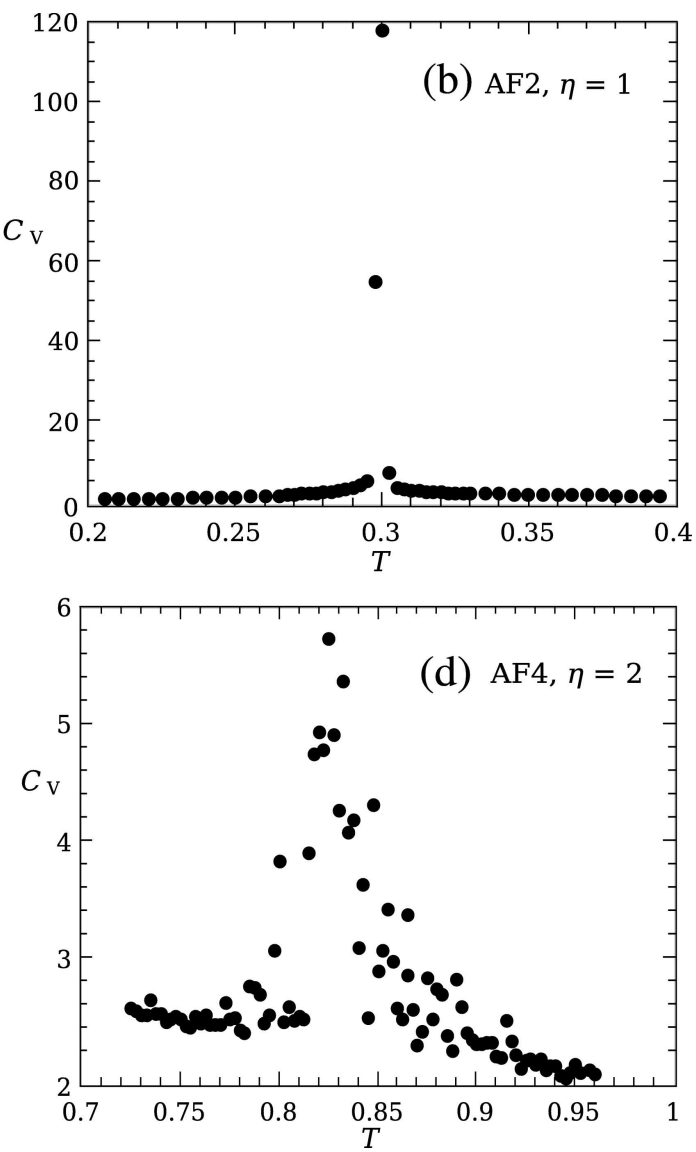

Fig. 2. Temperature dependences of specific heat close to the $T_{\mathrm{c}}$ point for (a) AF1, (b) AF2, (c) AF3, and (d) AF4 phases. 

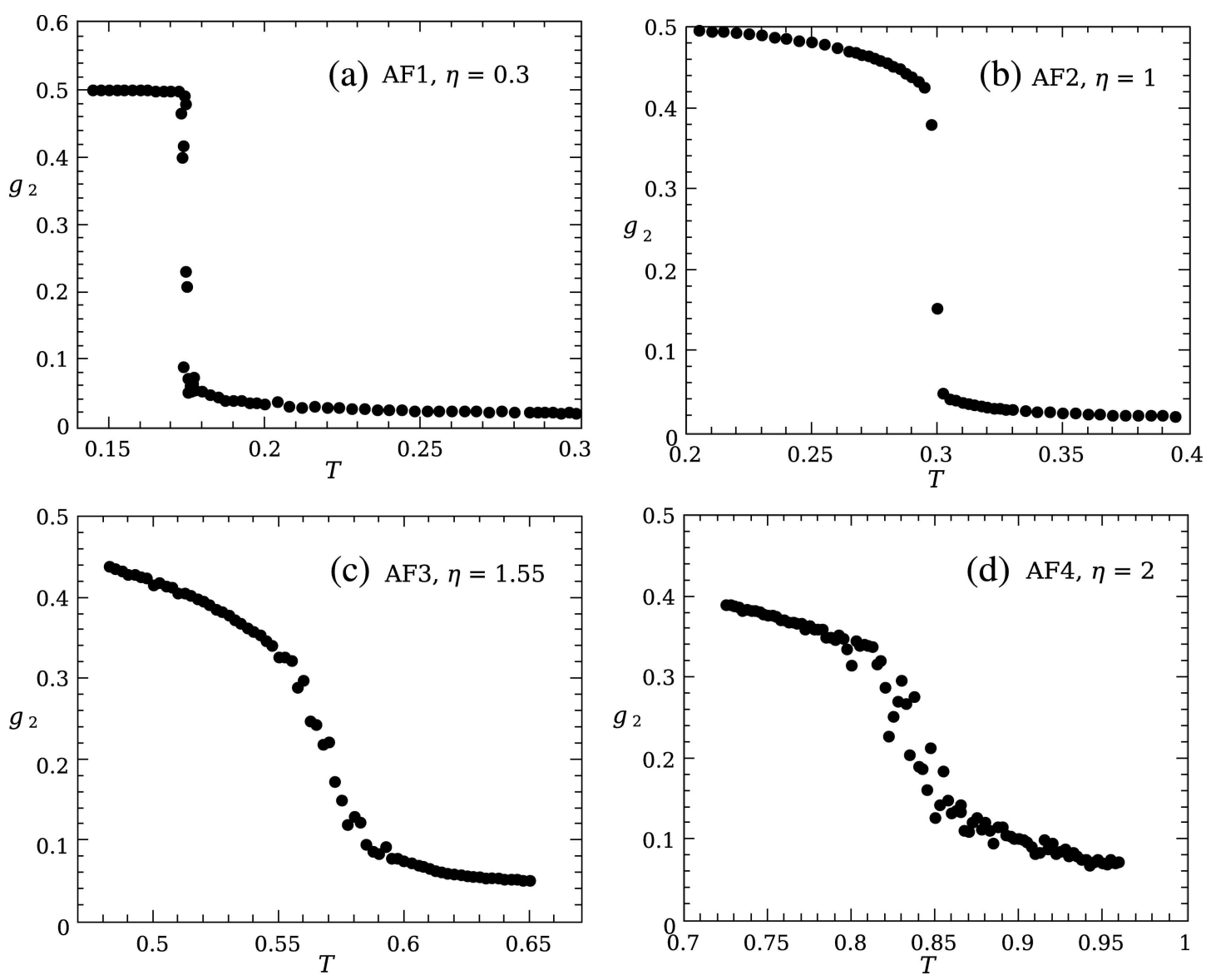

Fig. 3. Temperature dependences of order parameter close to the $T_{\mathrm{c}}$ point for (a) AF1, (b) AF2, (c) AF3, and (d) AF4 phases.

the energy histograms for hexagonal lattice we observe twin-peak $P(E)$ structure in the $\mathrm{AF} 1$ and $\mathrm{AF} 2$ phases and single peak structure for the AF3 and AF4 phases (see Fig. 6). Therefore the transition to the AF1 phase should also be attributed to the first order phase transitions, and the tricritical point separating first and second order phase transitions on the phase diagram has to be roughly at the AF2 and AF3 phase boundary. Figure 6(c) in a way corroborates the latter statement, because at $\eta=1.55$, which is very close to this boundary, the higher- $T$ phase peak structure with a lower- $T$ phase shoulder with decrease of temperature continuously changes into lower- $T$ phase peak and higher- $T$ phase shoulder. This behaviour is very similar to the $P(E)$ dependences at transition point of a 2D 4-state Potts model which has the second order phase transition very close to the tricritical point in $T$ versus states number dependence. The 2D 5-state Potts model has the twin-peak $P(E)$ structure, indicating weak first order phase transition [22].

\section{Structure factor}

We calculated the structure factor above and below transition temperatures to the $\mathrm{AF} 1, \mathrm{AF} 2, \mathrm{AF} 3$, and $\mathrm{AF} 4$ phases. The structure factor peaks in $\mathbf{k}$ space at $T \approx T_{\mathrm{C}}$ reflect the degeneracy of the system induced by the underlying lattice. At $T<T_{\mathrm{c}}$ they show the dominant stripe direction (see Fig. 7). The coordinates of the peaks in $\mathbf{k}$ space allows to distinguish between the phases of different stripe widths. Temperature dependences of the structure factor intensities are good indications of the phase transition point. The structure factor has the form

$$
S(\mathbf{k})=\left\langle\left|\sum_{\mathbf{r}} S(\mathbf{r}) \mathrm{e}^{\mathrm{i} \mathbf{k r}}\right|^{2}\right\rangle,
$$

where $\mathbf{r}=a m_{1} \mathbf{x}+a m_{2}(\mathbf{x} / 2+\sqrt{3} \mathbf{y} / 2)$ and $\mathbf{k}=$ $2 \pi\left[n_{1} \mathbf{x}+\left(2 n_{1}-n_{2}\right) \mathbf{y} / \sqrt{3}\right] / a$ are the basic vectors of direct and inverse hexagonal lattice respectively, $\mathbf{x}$ and $\mathbf{y}$ are unit vectors, and $n_{1,2}, m_{1,2}$ are whole numbers.

Above the phase transition to the AF1 phase small peaks are observed on a boundary of the hexagon indicating 6-fold degeneracy of the hexagonal system (Fig. 7(c)). At $T \approx T_{\text {c }}$ (Fig. 7(b)) six peaks might 

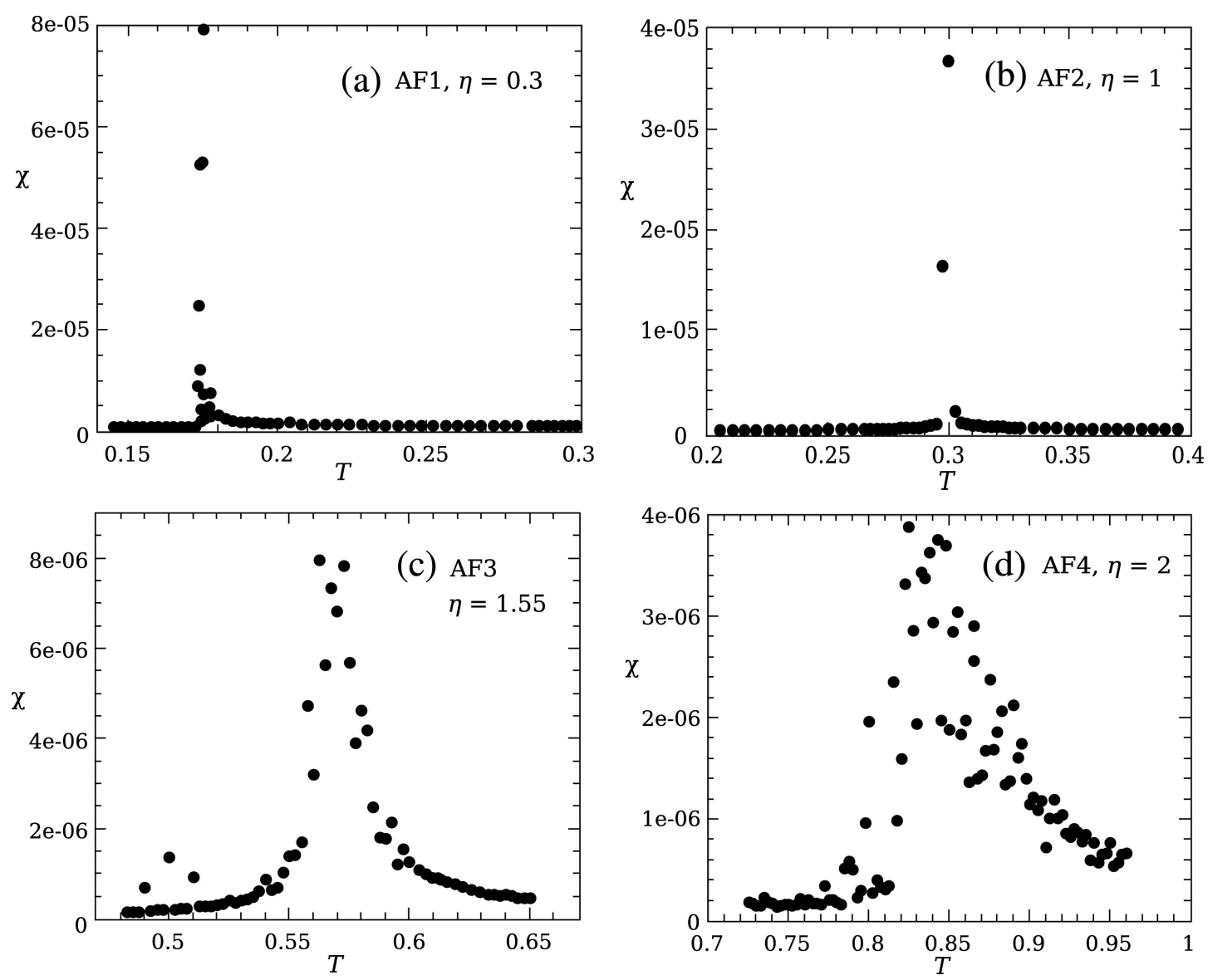

Fig. 4. Temperature dependences of susceptibility close to the $T_{\mathrm{c}}$ point for (a) AF1, (b) AF2, (c) AF3, and (d) AF4 phases.

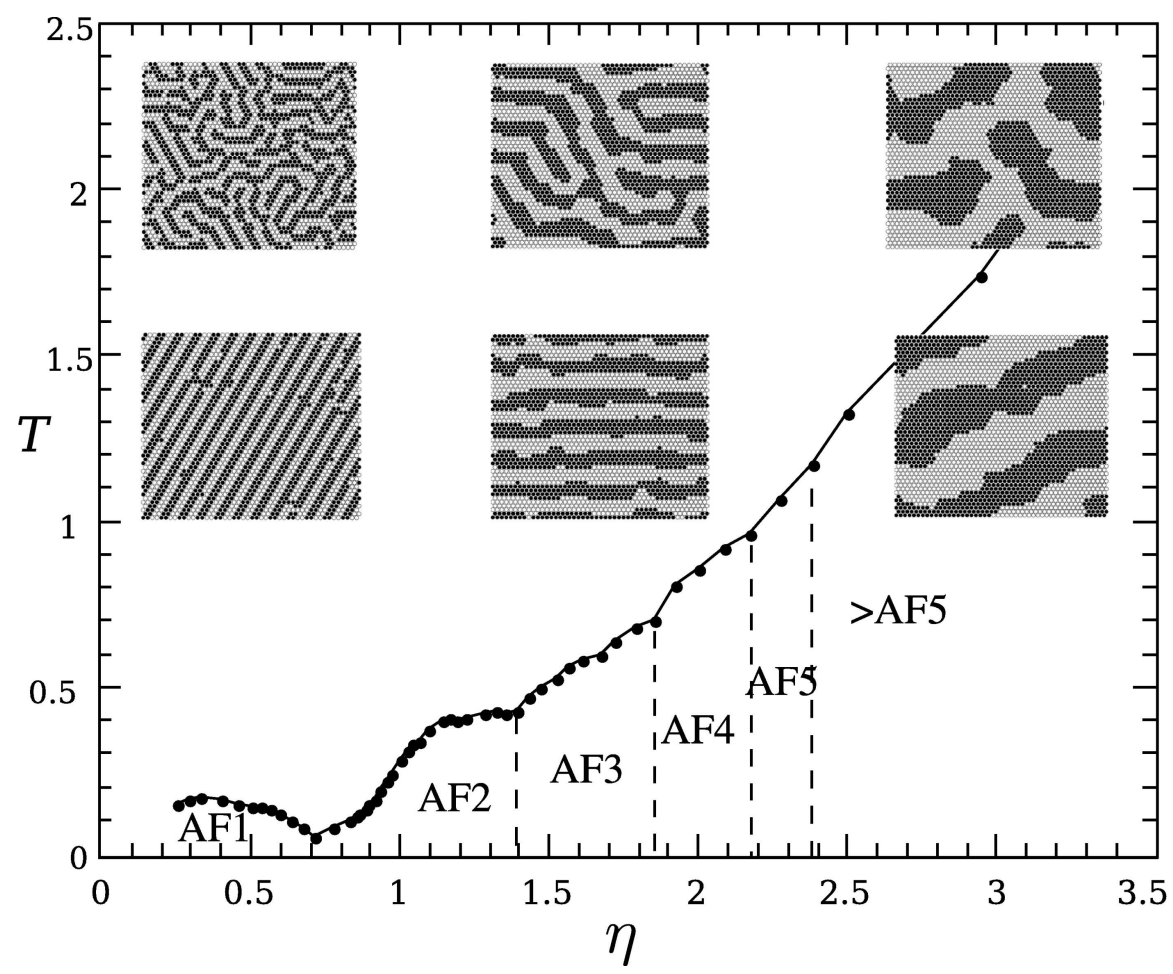

Fig. 5. Phase diagram in $(T, \eta=J / D)$ coordinates. Insets: snapshots of domains just above and below phase transition points for $\eta=1.1$ (AF2), $\eta=2$ (AF4), and $\eta=3.3$ (AF8-12). Black dots represent spins up, while white dots are for spins down. 

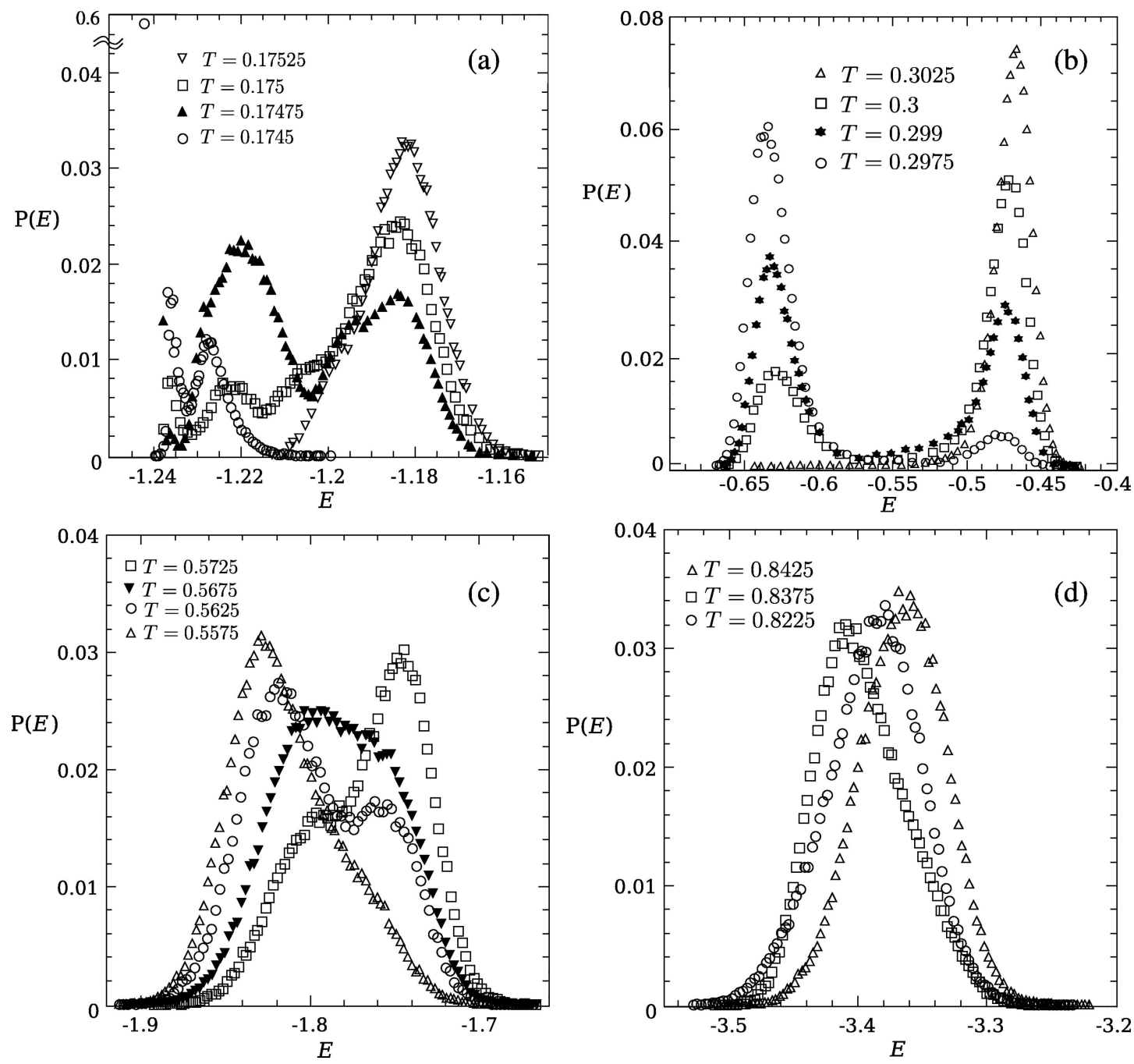

Fig. 6. Energy distribution histograms for several temperature values at the phase transition point: (a) $\eta=0.3$ (AF1 phase), (b) $\eta=1.0$ (AF2 phase), (c) $\eta=1.55$ (AF3 phase), and (d) $\eta=2.0$ (AF4 phase).

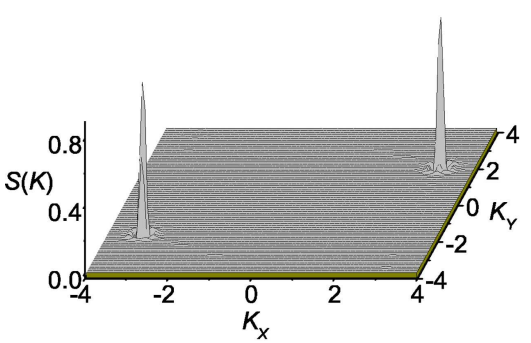

(a)

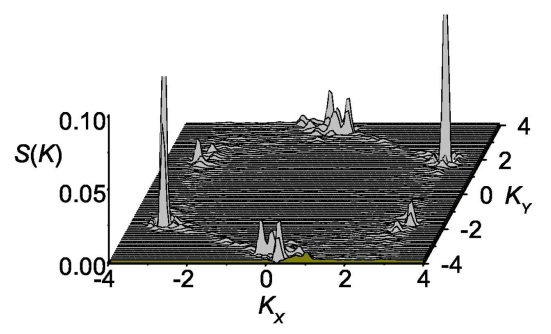

(b)

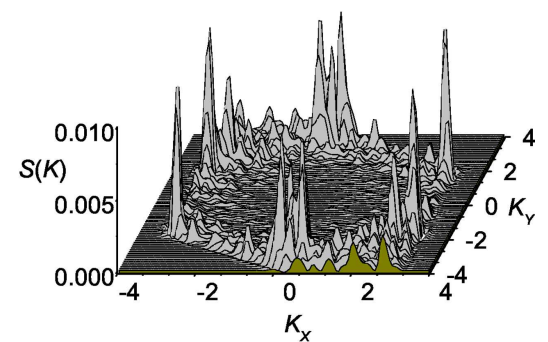

(c)

Fig. 7. Typical structure factor peaks for AF1 phase (here $\eta=0.3$ ): (a) $T<T_{\mathrm{c}}$, (b) $T \approx T_{\mathrm{c}}$, and (c) $T>T_{\mathrm{c}}$.

be well-distinguished in $\mathbf{k}$ space points $(0, \pm 2 \pi / \sqrt{3})$, $(\pi, \pm \pi / \sqrt{3})$, and $(-\pi, \pm \pi / \sqrt{3})$. At these values of temperature the system still did not "decide" to which of three directions of the hexagonal lattice to orient the stripe. At still lower temperature (Fig. 7(a)) dominant stripe direction is chosen: intensity of peaks at $(\pi, \pm \pi / \sqrt{3})$ is growing at expense of that of other peaks and at $T_{\mathrm{c}}$ attain the maximum value almost by jump. The temperature dependence of these peaks' intensity have almost one-to-one correspondence with the temperature dependence of the order parameter of the AF1 phase (Fig. 3(a)). 

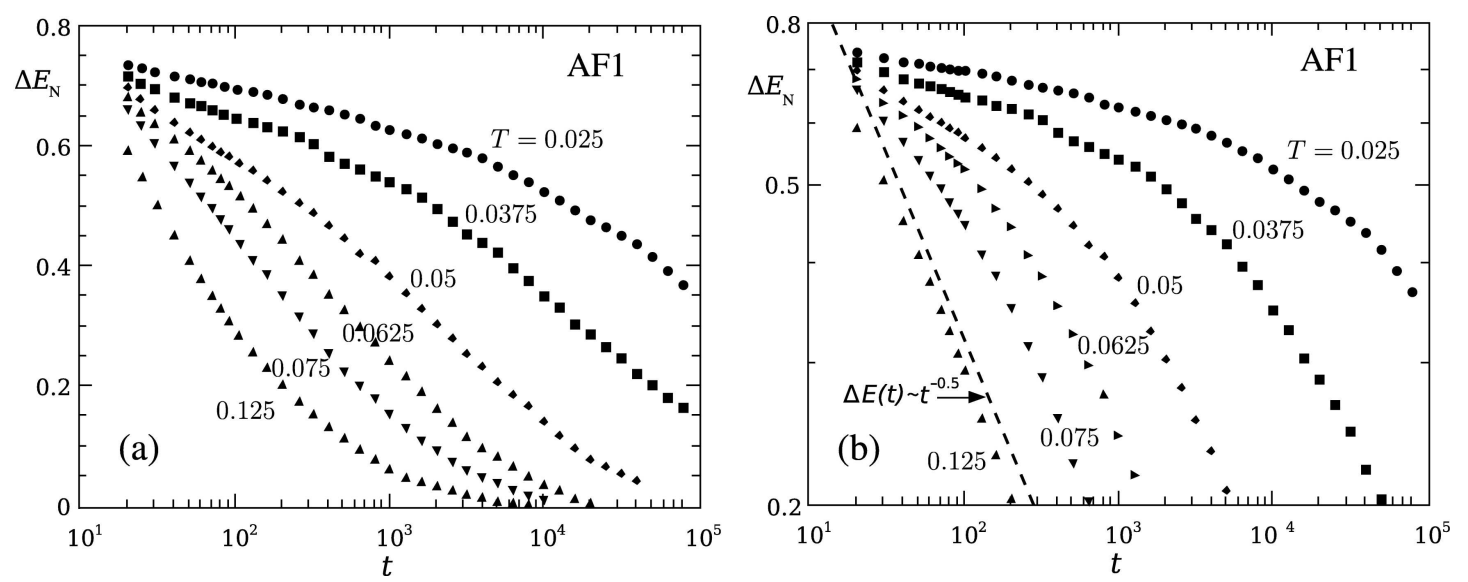

Fig. 8. Energy relaxation at $\eta=0.25$ in the AF1 phase: (a) semilog plot and (b) log-log plot. Quench temperatures are shown near the corresponding curves. Dashed line shows the Ising model dynamics.

The situation is similar in other phases at $T \approx$ $T_{\mathrm{c}}$. In AF2 phase the peaks are at $(0, \pm \pi / \sqrt{3})$, $(\pi / 2, \pm \pi /(2 \sqrt{3}))$, and $(-\pi / 2, \pm \pi /(2 \sqrt{3}))$, i. e. the sides of occuring hexagon in $\mathbf{k}$ space are two times shorter than those of the AF1 phase hexagon. Correspondingly the peaks in the AF3 phase are at $(0, \pm 2 \pi /$ $(3 \sqrt{3})),(\pi / 3, \pm \pi /(3 \sqrt{3}))$, and $(-\pi / 3, \pm \pi /(3 \sqrt{3}))$, in AF4 phase at $(0, \pm \pi /(2 \sqrt{3})),(\pi / 4, \pm \pi /(4 \sqrt{3}))$, and $(-\pi / 4, \pm \pi /(4 \sqrt{3}))$. At $T<T_{\mathrm{c}}$ only one pair of those peaks remains and increases up to the maximum value. It should be noted that in the AF3 and AF4 phases additional pair of smaller peaks are also found as in the calculations of the structure factor for the square lattice [7, 14].

\section{Dynamics}

We have also studied the dynamical properties of the model (1). The system was annealed at high temperatures and then quenched to temperatures below the transition temperature $T_{\mathrm{c}}$ (to avoid the fluctuations, we usually used the temperature $T<0.6 T_{\mathrm{c}}$ as a quench temperature). We monitored how the energy $E(t)$ of a disordered system relaxes to the ground state stripe phase energy $E(\infty)$, here $t$ is the time measured in Monte Carlo steps (MCS) per site. The final curves are obtained by averaging over 20-50 $E(t)$ dependences. It is known that for the Ising-type models (e.g. when $D=0$ in (1)) the size of a ferromagnetic domain $R$ grows with time as $R \sim \Delta E^{-1} \sim t^{0.5}$ [23-25], where $\Delta E=E(t)-E(\infty)$. The same result was found studying the dynamics of the AF1 stripe domain on a square lattice [12]. Here we study the dynamics for all the phases found in the phase diagram for hexagonal lattice (Fig. 5), presenting the results for AF1, AF2, $\mathrm{AF} 3$, and AF4.
In Fig. 8 we present the time dependences of the normalized energy difference $\Delta E_{N}=\Delta E /[E(0)-$ $E(\infty)]$ for $\eta=0.25$. The Fig. 8(a) represents typical dynamics of the AF1 phase: for higher quench temperature the curve immediately goes down to saturation, while for lower temperature critical slowing down at starting times is clearly seen. In log-log scale (Fig. 8(b)) we can recognize the Ising model dynamics. The growth of the AF1 phase domain is demonstrated in Fig. 9 as a series of snapshots at different moments of time.

In Fig. 10 we show the energy relaxation curves for three values of the interaction parameter $\eta(0.25,0.33$, and 0.5 ) which are in the AF1 phase region of the phase diagram. It is interesting to note that for any chosen temperature inside the $\mathrm{AF} 1$ phase, the data points for all 3 values of $\eta$ fall onto one curve, indicating that the dynamics inside the AF1 phase is the same for all $\eta$ values, and the domain growth in this phase follows the $\sim t^{0.5}$ law. The dynamics in the AF2 phase is more complicated. The curves are concave and sloppy indicating some saturation for highest temperature as in the AF1 phase, but the relaxation is clearly slower (see Fig. 11). Some curves obtained for higher values of temperature even satisfy the exponential dependence, but still no definite answer about the relaxation dynamics can be given. We consider this behaviour as intermediate between the Ising-type dynamics of the AF1 phase and much slower dynamics of the broader stripe phases.

Time dependences of $\Delta E_{N}$ for AF3 and AF4 phases are presented in Fig. 12. The dynamics is slow and up to $10^{5} \mathrm{MCS} / \mathrm{s}$ clearly follows the $\Delta E(t) \sim(\log t)^{-1}$ dependence. This law still holds for phases with $h=5$ and 6. For higher values of $\eta$ it has to give way to Ising model dynamics again, since at higher values of $\eta$ 


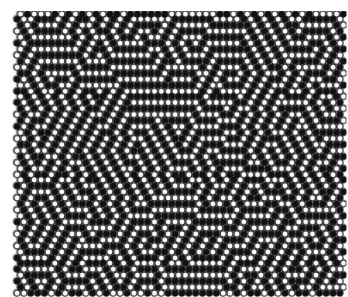

(a) $100 \mathrm{MCS}$

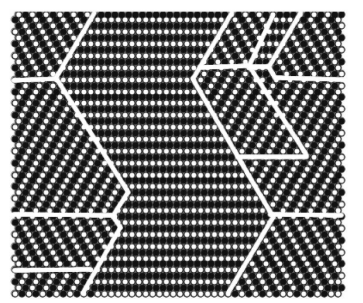

(d) $5000 \mathrm{MCS}$

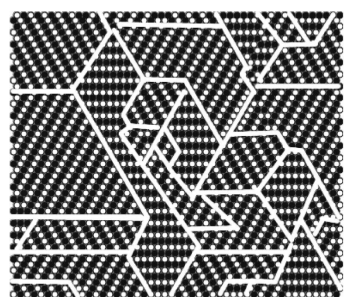

(b) $2000 \mathrm{MCS}$

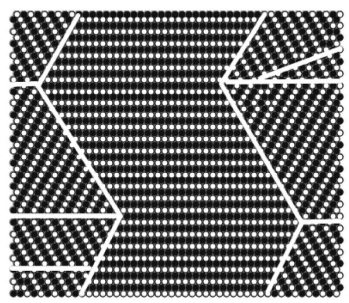

(e) $10000 \mathrm{MCS}$

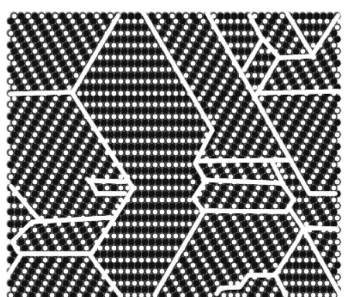

(c) $3000 \mathrm{MCS}$

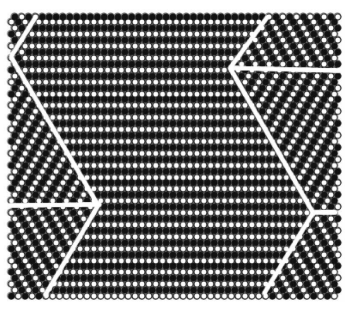

(f) $15000 \mathrm{MCS}$

Fig. 9. Snapshots of the growth of the AF1 phase domain at different times measured by Monte Carlo steps per site. Black and white dots represent stripes of different orientation. White lines show borders of different domains.
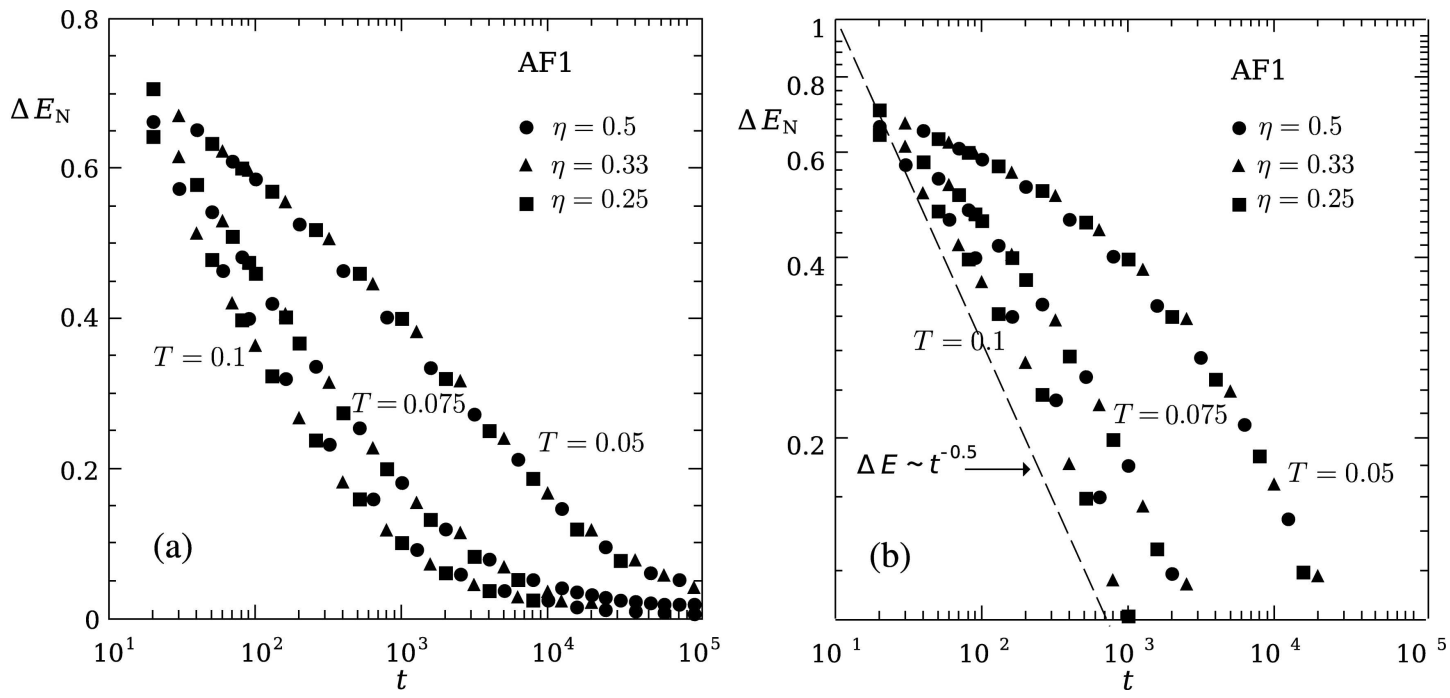

Fig. 10. Energy relaxation for three $\eta$ values in the AF1 phase and three values of quench temperature: (a) semilog plot and (b) log-log plot. Dashed line shows the Ising model dynamics.

phases with very broad stripes or FM phase occur. The calculations of $\Delta E_{N}(t)$ for the phase at $\eta=3.3$ ( $h$ is varying and might be between 8 and 12) confirmed this prediction. Obviously it must also hold for the stripes that are broader than the lattice size used in our calculations.

\section{Discussion}

It should be noted that in AF1, AF2, AF3, and AF4 phases and the isotropic short-range stripe phases, to which those mentioned phases pass above the transition point, the stripe width is fixed and it does not vary with temperature up to very high temperature. The situation is different for higher values of $\eta$ : stripe width is varying and cannot be unambigously defined in AF $h$ with $h \geq 6$ (compare the snapshots of insets in Fig. 5 at the transition point in AF2, AF4, and AF8-12 phases). Varying stripe width in broader-stripe phases might be related to higher $T_{\mathrm{c}} \mathrm{s}$ and correspondingly stronger fluctuations in the system. On the other hand, variation of stripe width is also observed at lower temperature, thus 

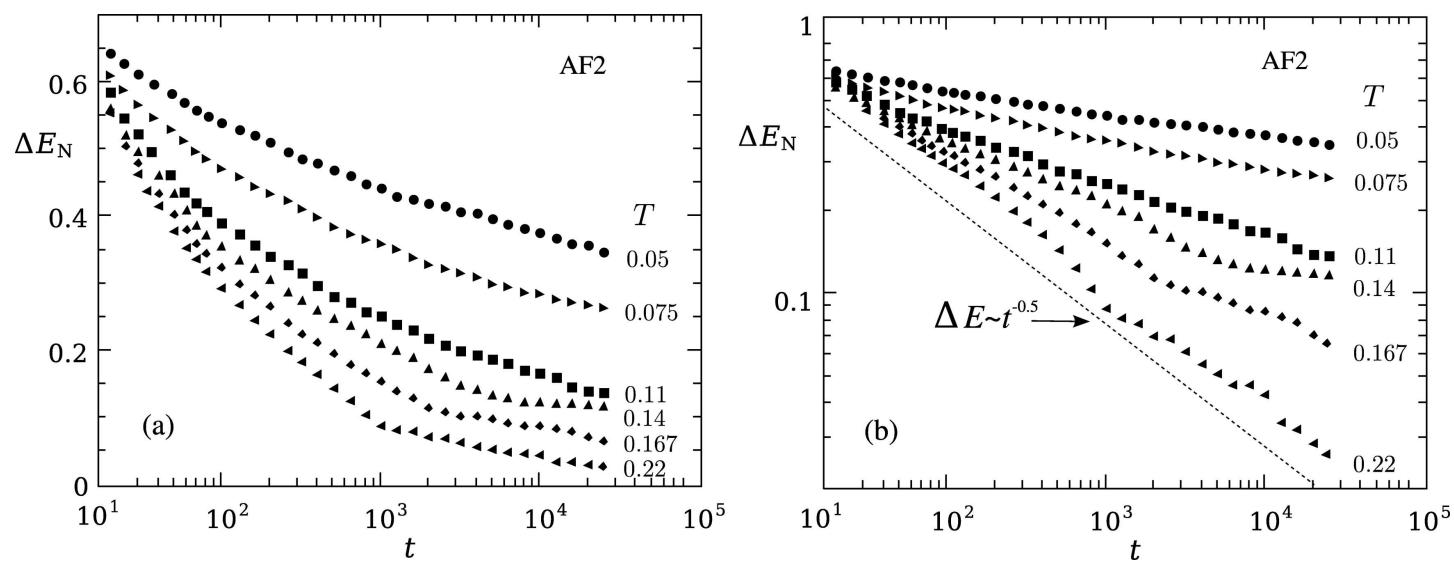

Fig. 11. Energy relaxation in the AF2 phase at $\eta=1.1$ : (a) semilog plot and (b) log-log plot. Quench temperatures are shown near the corresponding curves. Dashed line shows the Ising model dynamics.

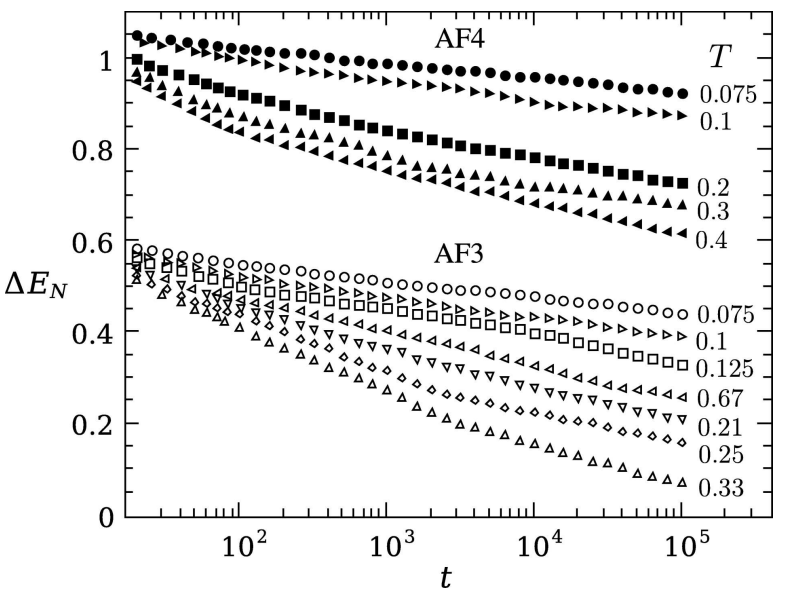

Fig. 12. Semilog plots of energy relaxation in the AF3 and AF4 phases. Upper curves at $\eta=2$ (AF4 phase), lower curves at $\eta=$ 1.67 (AF3 phase). AF4 curves are vertically shifted for clarity by 0.5 . Quench temperatures are shown near the corresponding curves.

the underlying reason could be related to effects of elasticity, dislocations, or defects which can stronger manifest themselves in large-domain systems.

Monitoring the stripe structures above the transition point, we did not find any indication of the paramagnetic phase - the phase above the transition point was isotropic short-range stripes (hexatic) phase in a whole range of $\eta$ values of our phase diagram. According to predictions of the analytic theory [17], the melting of narrow and average-width stripes proceeds through isotropic short-range stripes phase, while the melting of very broad stripes is related to spin disordering. Two examples of intermediate short-range stripe phase used in calculation on a square lattice [8] were taken for stripe phases of average widths, $h=4$ and 8 . In our calculations we still see the transition from isotropic to straight stripes at $\eta \leq 5$. At $\eta=5$ we find two broad stripes in our $48 \times 48$ pattern $(h \approx 10-15)$, but no spin

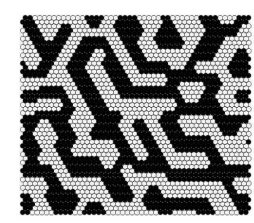

(a)

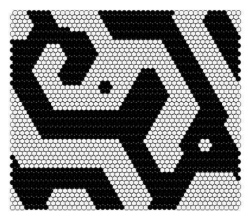

(b)

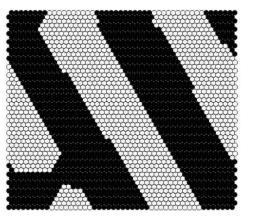

(c)
Fig. 13. Width of stripe domains for $\eta=3.3$ and relaxation for $10^{5} \mathrm{MCS} / \mathrm{s}$ after a quench to different temperatures: (a) $T=0.09$, (b) $T=0.3$, and (c) $T=0.9$.

disordering (paramagnetic phase). At $\eta=10$ either FM phase, or the phase with the stripe width larger than the lattice size is observed.

Studying the dynamics of the stripe phase at $\eta=$ 3.3, we found one interesting feature which was not observed for phases AF1-AF4: the size $h$ of stripe domains after a quench to different temperatures and relaxation for $10^{5} \mathrm{MCS} / \mathrm{s}$ was clearly different: very small for quench to very low $T(h=3-4)$ and more or less characteristic of these $\eta$ values $(h \approx 8-12)$ for quench to $T \approx T_{\mathrm{c}} / 2$ (see Fig. 13). This shows that critical slowing down at low $T$ and large values of $\eta$ is much stronger than that for small $\eta$. Moreover, it demonstrates the process of stripe growth which could not be observed at small $\eta$, because the stripes in phases $\mathrm{AF} 1-\mathrm{AF} 4$ are too thin. Thus, the phase grows first forming thin stripes and then making them thicker and thicker until they reach the $h$ value characteristic of given $\eta$ value.

Studying snapshots for $\eta=3.3$ at high and lower temperatures, a slight ripening of stripes is also observed with decrease of temperature, the fact well documented in experiments $[4,5]$. 


\section{Summary}

We have studied by using Monte Carlo method the magnetic spins system on a hexagonal lattice, where the spins interact by means of ferromagnetic exchange $J$ and dipole-dipole $D$ interactions. The stripe melting phase transition from stripe phase to short-range isotropic stripe phase with extended domains, within which the spins are ordered but do not possess directional and translational symmetries of the striped phase, is obtained from temperature dependences of specific heat and susceptibility for different values of the interaction ratio $\eta=J / D$. This transition at temperature point $T_{\mathrm{c}}$ proceeds via straightening of stripes due to a symmetry breaking field which removes the degeneracy of stripe orientations induced by hexagonal lattice and introduces the long-range stripe order. Stripe width $h$ in a stripe phase AF $h$ depends on $\eta=J / D$. We obtained the phase diagram of the system for different $\mathrm{AF} h$ phases. By using histogram method we determined the existence of the first order (to the AF1 and $\mathrm{AF} 2$ phases) and the second order (to the AF3 and AF4 phases) phase transitions. We calculated temperature dependences of the structure factor above and below phase transition points to AF1, AF2, AF3, and AF4 phases. We have also studied the dynamical properties of the chosen model by quenching the spin system equilibrated at high temperatures to $T<T_{\mathrm{c}}$ and following how the energy $E(t)$ of a disordered system relaxes to the ground state stripe phase energy $E(\infty)$. For the Ising-type models (e.g. when $D=$ $0)$ the size of ferromagnetic domain grows as $R \sim$ $(E(t)-E(\infty))^{-1} \sim t^{0.5}$, where $t$ is the time measured in MC steps. We have found that in AF1 phase and in a part of AF2 phase relaxation dynamics corresponds to the Ising model dynamics. However, with increase of $\eta$ value (in phases AF3 and AF4) the dynamics slows down and relaxation is $\Delta E(t) \sim(\log t)^{-1}$. Therefore it cannot be excluded that the dynamics in this region belongs not to Ising model universality class, but to that of more complicated models, e. g. planar (KosterlitzThouless) model. With further increase of $\eta$, when the domain size becomes comparable to the lattice size and we approach the ferromagnetic phase in the phase diagram, the dynamics satisfies the $t^{-0.5}$ law again.

\section{Acknowledgements}

We are grateful to Vytautas Petrauskas for technical assistance. This work was partly supported by the project MULTIMA (No C-18/2007) of Lithuanian State Science and Studies Foundation.

\section{References}

[1] M. Seul and M.J. Sammon, Competing interactions and domain-shape instabilities in a monomolecular film at an air-water interface, Phys. Rev. Lett. 64, 1903-1906 (1990).

[2] K. Kern, H. Niehus, A. Schatz, P. Zeppenhfeld, J. Goerge, and G. Comsa, Long-range spatial selforganization in the adsorbate-induced restructuring of surfaces: $\mathrm{Cu}(110)-(2 \times 1) \mathrm{O}$, Phys. Rev. Lett. 67, 855858 (1991).

[3] T. Mitsui and J. Furuichi, Domain structure of Rochelle Salt and $\mathrm{KH}_{2} \mathrm{PO}_{4}$, Phys. Rev. 90, 193-202 (1953).

[4] R. Allenspach and A. Bischof, Magnetization direction switching in epitaxial $\mathrm{Fe} / \mathrm{Cu}(100)$ films: Temperature and thickness dependence, Phys. Rev. Lett. 69, 33853388 (1992).

[5] A. Vaterlaus, C. Stamm, U. Maier, M.G. Pini, P. Politi, and D. Pescia, Two-step disordering of perpendicularly magnetized ultrathin films, Phys. Rev. Lett. 84, 22472250 (2000).

[6] O. Portmann, A. Vaterlaus, and D. Pescia, An inverse transition of magnetic domain patterns in ultrathin films, Nature 422, 701-704 (2003).

[7] A.B. MacIsaak, J. P. Whitehead, M.C. Robinson, and K. De'Bell, Striped phases in two-dimensional dipolar ferromagnets, Phys. Rev. B 51, 16033-16045 (1995).

[8] I. Booth, A.B. MacIsaac, J.P. Whitehead, and K. De'Bell, Domain structures in ultrathin magnetic films, Phys. Rev. Lett. 75, 950-953 (1995).

[9] Ar. Abanov, V. Kalatsky, V.L. Pokrovsky, and W.M. Saslow, Phase diagram of ultrathin ferromagnetic films with perpendicular anisotropy, Phys. Rev. B 51, 1023-1038 (1995).

[10] K. De'Bell, A.B. MacIsaac, and J.P. Whitehead, Dipolar effects in magnetic thin films and quasi-twodimensional systems, Rev. Mod. Phys. 72, 225-257 (2000).

[11] P.M. Gleiser, F.A. Tamarit, and S.A. Cannas, Metastable states in a two-dimensional Ising model with dipolar interactions, Physica D 168-169, 73-79 (2002).

[12] P.M. Gleiser, F.A. Tamarit, S.A. Cannas, and M.A. Montemurro, Slow dynamics in a twodimensional Ising model with competing interactions, Phys. Rev. B 68, 134401-1-6 (2003).

[13] L.C. Sampaio, M.P. de Albuquerque, and F.S. de Menezes, Magnetic relaxation and formation of magnetic domains in ultrathin films with perpendicular anisotropy, Phys. Rev. B 54, 6465-6472 (1996).

[14] E. Rastelli, S. Regina, and A. Tassi, Phase transitions in a square Ising model with exchange and dipole interactions, Phys. Rev. B 73, 144418-1-11 (2006). 
[15] E. Rastelli, S. Regina, and A. Tassi, Order-disorder phase transition in two-dimensional Ising model with exchange and dipole interactions, J. Appl. Phys. 99, 08F708-1-3 (2006).

[16] S.A. Cannas, D.A. Stariolo, and F.A. Tamarit, Stripetetragonal first-order phase transition in ultrathin magnetic films, Phys. Rev. B 69, 092409-1-4 (2004).

[17] A.D. Stoycheva and S.J. Singer, Stripe melting in a two-dimensional system with competing interactions, Phys. Rev. Lett. 84, 4657-4660 (2000).

[18] A.D. Stoycheva and S.J. Singer, Computer simulations of a two-dimensional system with competing interactions, Phys. Rev. B 65, 036706-1-15 (2002).

[19] J.V. Jose, L.P. Kadanoff, S. Kirkpatrick, and D.R. Nelson, Renormalization, vortices and symmetry-breaking perturbations in the two-dimensional planar model, Phys. Rev. B 16, 1217-1241 (1977).

[20] C.N. Lapilli, P. Pfeiger, and C. Wexler, Universality away from critical points in two-dimensional phase transitions, Phys. Rev. Lett. 96, 140603-1-4 (2006).

[21] In (1) we consider the sum over every pair of spins in dipolar term just once as in Ref. [11]. Therefore in comparison with Refs. [7,14] the magnitudes of our $\eta$ and $T_{\mathrm{c}}$ are twice less.

[22] J. Lee and J.M. Kosterlitz, New numerical method to study phase transitions, Phys. Rev. Lett. 65, 137-140 (1990).

[23] A. Sadiq and K. Binder, Dynamic of the formation of two-dimensional ordered structures, J. Stat. Phys. 35, 517-585 (1984).

[24] G.S. Grest and D.J. Srolovitz, Impurity effects on domain-growth kinetics. I. Ising model, Phys. Rev. B 32, 3014-3020 (1985).

[25] P.J. Kundrotas, E.E. Tornau, and A. Rosengren, Dynamics of oxygen ordering in the cell-doubled phase of $\mathrm{YBa}_{2} \mathrm{Cu}_{3} \mathrm{O}_{6+x}$, Phys. Rev. B 54, 4357-4362 (1996).

\title{
MAGNETINIU JUOSTU TERMODINAMINIU IR DINAMINIŲ SAVYBIU MODELIAVIMAS DVIMATE்JE HEKSAGONINE்JE GARDELE்JE
}

\author{
A. Joknys, E.E. Tornau \\ Puslaidininkiu fizikos institutas, Vilnius, Lietuva
}

\section{Santrauka}

Kai kuriuose plonuose magnetiku sluoksniuose ir nanodariniuose, be artiveikių pamaininių sąveiku tarp magnetiniu sukinių, veikia ir toliveikès dipolinès jègos. Jeigu šios dvi sąveikos yra konkuruojančios (pvz., pamaininė yra feromagnetinė (FM), o sąveika tarp dipoliu - antiferomagnetinè (AF)), sistemoje gali atsirasti besikartojančios vienos krypties sukiniu juostos, atskirtos tokio pat storio priešingos krypties sukiniu juostomis, vadinamos dryžiais. Tokios juostos randamos ne tik magnetikuose, pvz., iš dalies deguonimi padengtame $\mathrm{Fe}(110)$ ar labai plonuose $\mathrm{Fe} / \mathrm{Cu}(001)$ sluoksniuose. Jos būdingos daugeliui saviformavimo būdu atsiradusių fizikinių ir net biologinių sistemų.

Šiame darbe mes modeliavome sukinių sistemą su konkuruojančiomis pamaininėmis ir dipolinėmis sąveikomis heksagoninèje gardelèje. Sukiniai yra gardelès mazguose, jų kryptis statmena gardelès plokštumai. Sukinių sąveikos energija $E=-J \sum_{i, j} s_{i} s_{j}+$ $D \sum_{i, j} s_{i} s_{j} / r_{i j}^{3}$. Čia $J-$ FM pamaininių sąveiku konstanta, o $D-$ dipolinių sąveikų konstanta. Dvi magnetinio sukinio būsenos gardelès $i$ mazge yra aprašomos sukinio kintamuoju $\sigma_{i}= \pm 1$. Pirma suma apima artimiausius kaimynus, antra - visus gardelès mazgus. Monte Karlo metodu mes apskaičiavome minètos sukinių sistemos energijos, šiluminès talpos, tvarkos parametro ir magnetinio jautrio priklausomybes nuo temperatūros. Iš šių parametrų anomalijų nustatėme fazinio virsmo taškus $T_{\mathrm{c}}$ tarp juostų fazès, pasižyminčios tolimaja tvarka, ir susisukusių juostų fazès, pasižyminčios tik artimaja tvarka. Žemose temperatūrose atsiranda ịvairaus pločio juostų fazès, o juostos plotis $h$ (gardelès konstantos vienetais) priklauso nuo $J / D$ santykio. Tokiu būdu mes apskaičiavome fazinę diagramą temperatūros ir parametro $J / D$ koordinatèse ìvairaus pločio juostu dariniams (AF1 $(h=1), \operatorname{AF} 2(h=2)$ ir t. t.). Histogramu metodu nustatėme, kad fazinejje diagramoje egzistuoja ir pirmos (i $\mathrm{AF} 1$ ir AF2 sritis), ir antros (i AF3 ir AF4 sritis) rūšies faziniai virsmai. Taip pat apskaičiavome sistemos struktūrinio faktoriaus priklausomybes nuo temperatūros, kai temperatūra yra aukštesnè ir žemesnè už fazinio virsmo i AF1, AF2, AF3 ir AF4 fazes temperatūrą. Struktūrinis faktorius parodo, kaip dèl heksagoninès gardelès išsigimusi sistema, mažèjant temperatūrai, palaipsniui praranda išsigimimą ir pasirenka vieną iš trijų galimų juostų orientacijų.

Mes taip pat nagrinejome dinamines modelio savybes. Aukštoje temperatūroje atkaitinta sukinių sistema buvo staigiai užgrūdinama, ją patalpinant žemoje $\left(T<T_{\mathrm{c}}\right.$ ) temperatūroje, o toliau sekama, kaip netvarkios sistemos energija $E(t)$ relaksuoja i pagrindinę juostų būsenos energiją $E(\infty)$. Yra žinoma, kad Izingo tipo modeliuose (pvz., kai $g=0$ (1)) FM domeno dydis virsmo aplinkoje auga taip: $R \propto 1 / \Delta E \propto t^{0,5}$, kur $\Delta E=E(t)-E(\infty)$ o $t$ yra laikas, matuojamas Monte Karlo žingsnių skaičiumi. Nustatème, kad AF1 fazèje ir dalyje AF2 fazès sukinių relaksacinè dinamika atitinka minètą Izingo modelio dèsnị. Tačiau didejjant $J$ vertei (AF3 ir AF4 fazèse) relaksacija yra kitokia: $1 / \Delta E \propto \ln t$. Todèl gali būti, kad dinamika toje srityje priklauso nebe Izingo, o Kosterlico ir Tauleso faziniu virsmu klasei. Toliau didinant $J$ ir fazinèje diagramoje artejjant prie FM fazès, dinamika vèl tenkina $\Delta E \propto t^{-0,5}$ dèsnị. 